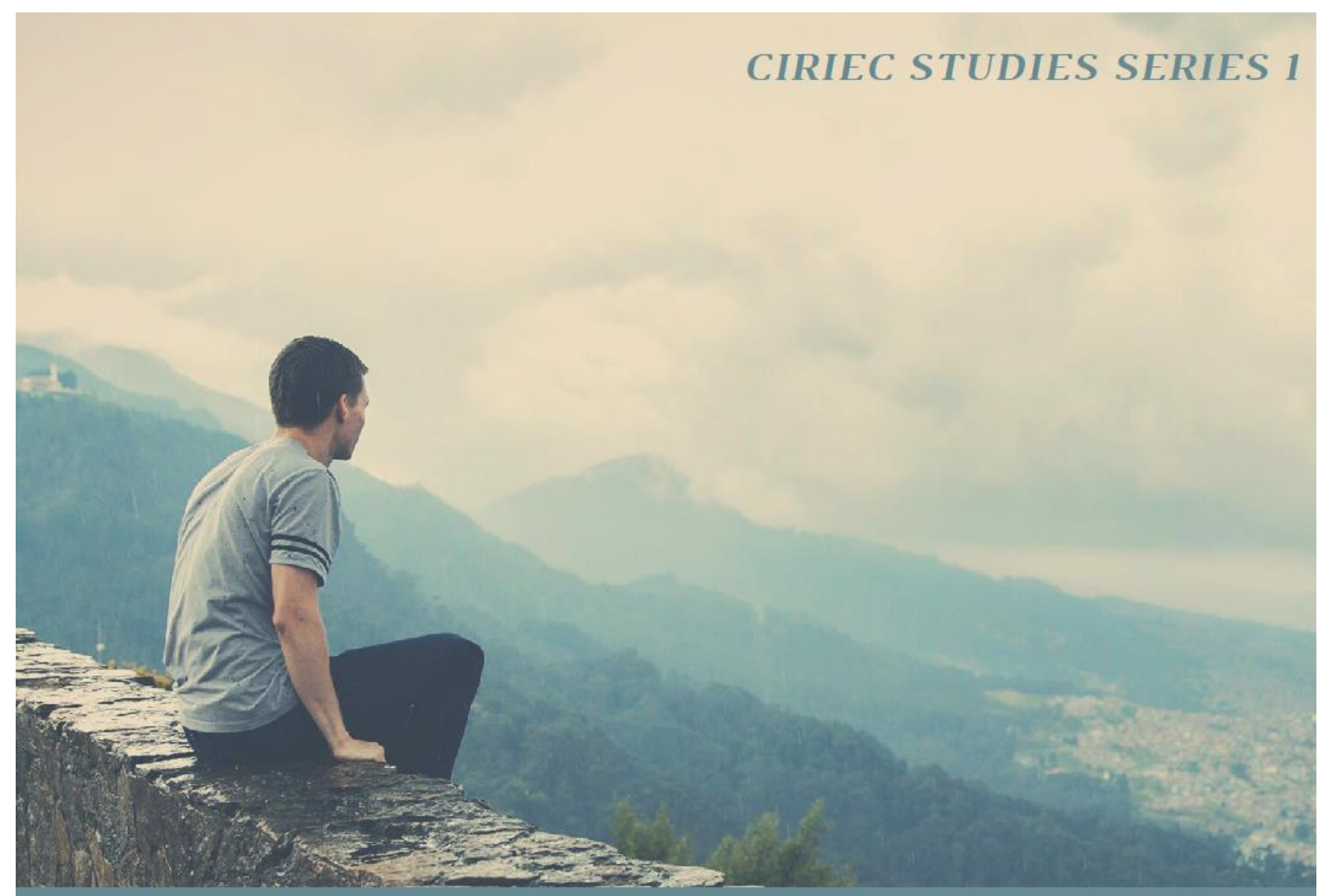

CHAPTER 6

UNDERSTANDING FINANCIALIZATION AND ITS IMPACTS ON SOCIAL ECONOMY

Manuel Belo Moreira

Part of Providing public goods and commons. Towards coproduction and new forms of governance for a revival of public action by Philippe BANCE (dir.), 2018 


\section{CIRIEC (International Centre of Research and Information on the Public, Social and Cooperative Economy) is a non-governmental international scientific organization.}

Its objectives are to undertake and promote the collection of information, scientific research, and the publication of works on economic sectors and activities oriented towards the service of the general and collective interest: action by the State and the local and regional public authorities in economic fields (economic policy, regulation); public utilities; public and mixed enterprises at the national, regional and local levels; the so-called "social economy" (not-for-profit economy, cooperatives, mutuals, and non-profit organizations); etc.

In these fields CIRIEC seeks to offer information and opportunities for mutual enrichment to practitioners and academics and to promote international reflection and action

CIRIEC activities, publications and researches are realized with the support of
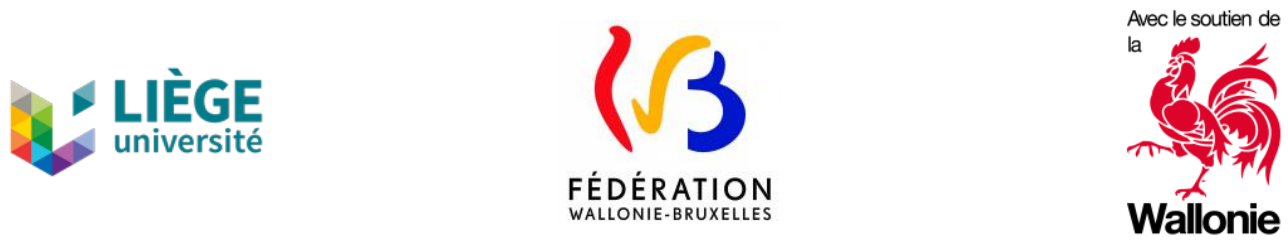

This publication has been peer-reviewed.

No part of this book may be reproduced in any form, by print, photocopy, microfilm or any other means, without prior written permission from the publisher. All rights reserved.

(C) CIRIEC aisbl, 2018

Université de Liège

Quartier Agora

Place des Orateurs, 1

Bât. B33, bte 6, BE-4000 Liège

ciriec@uliege.be; http://www.ciriec.uliege.be

BELO MOREIRA, Manuel. “Understanding financialization and its impacts on Social Economy / Chapter 6". In: CIRIEC and BANCE, Philippe (dir.). Providing public goods and commons. Towards coproduction and new forms of governance for a revival of public action. Liège: CIRIEC, 2018.

(CIRIEC Studies Series; 1), pp. 113-133.

http://doi.org/10.25518/ciriec.css1chap6

This publication is indexed and available in RePEc 


\title{
Understanding financialization and its impacts on Social Economy / Chapter 6
}

\author{
Manuel BELO MOREIRA*
}

\begin{abstract}
Following a political economy perspective about financialization and its impacts on social economy, it seems important to understand the role of the neoliberal ideological hegemony and the ways in which, it not only influences academic thinking, but it goes well beyond, by shaping the "common sense" and therefore reinforcing its dominance.

Describing the essential features of the financialization process brings to light the driving forces and the mechanisms that were put into practice and, finally, explains why, in spite of its negative effects which could provoke a rejection by the majority, the ideology is nonetheless reinforced.

The text seeks to establish a framework concerning the impacts of financialization on the social economy sector, by reflecting what the main differences are between the different branches of social economy and how they can be affected by neoliberal ideology and policies. It seems particularly important to separate the institutions of social economy that do not compete with profit firms from the institutions that by competing on the market could function as an alternative to capitalist enterprises.
\end{abstract}

Keywords: financialization; social economy; neoliberal ideology

JEL-Codes: L31, J54, O35

\footnotetext{
* Prof. Universidade de Lisboa, Instituto Superior de Agronomia; member of CIRIEC-Portugal (Portugal) (mbelomoreira@isa.utl.pt).
} 


\section{Introduction}

If we accept that the Great Recession is nothing else than the result of what is called the financialization of the economy, that brought about the global financial crisis initiated in 2007/8, provoking the sovereign debt crisis in Europe, it would appear that reflection on this theme, following a political economic approach, is particularly important to social economy (SE) ${ }^{1}$.

The enormous amount of literature about financialization calls for a short synthesis of what financialization means as well as its recognized impacts (Moreira, 2017). However, most of the literature does not pay enough attention to the driving forces that help to understand and explain the scale and scope of this process. One needs to examine the ideological ingredients that paved the way to the hegemony of the neoliberal ideology and hence the political will that led to the financialization. When the global crisis emerged, neoliberal ideology successfully worked to "Never Let a Serious Crisis Go to Waste: How Neoliberalism Survived the Financial Meltdown" as the title of Mirowsky's (2013) work perfectly illustrates.

Many authors have already called the attention to the role of the ideology, but my preferred quote comes from Keynes:

\footnotetext{
"The ideas of economists and political philosophers, both when they are right and when they are wrong, are more powerful than is commonly understood. Indeed the world is ruled by little else. Practical men, who believe themselves to be quite exempt from any intellectual influence, are usually the slaves of some defunct economist. ... But, soon or late, it is ideas, not vested interests, which are dangerous for good or evil."”
}

My argument is that only when the history of the emergence and consolidation of the hegemony of the neoliberal ideology and its effects (not only within the academic, economic, social and political realm, but also on popular culture) is clearly assessed and understood, it will be possible to present a coherent logical explanation to the financialization process and its impacts on the role of social economy on the economies and societies of the second decade of the XXI century.

The aim of the next section is to provide a short explanation of the emergence and consolidation of the hegemonic status of the neoliberal ideology which, in general terms, still prevails giving particular emphasis to how common sense is being shaped and how it contributes to the reinforcement of the power of the neoliberal ideology.

Section two deals with the main aspects of the globalization process and in particular with the main consequences of what is meant by financialization.

\footnotetext{
${ }^{1}$ The social economy is still a controversial concept. Many confuse social economy with non-profit institutions. However, for many others, it seems that it must go beyond non-profit: implying the democratic rule; that members receive at most limited compensation on capital subscribed and no private appropriation of the surplus realized and/or patrimonial plus values are allowed, apart from other items such as the ones referred to by the International Cooperative Alliance. In this text the concept proposed by Social Economy Europe at http://www.socialeconomy.eu.org/social-economy will be used.

${ }^{2}$ https://en.wikiquote.org/wiki/John_Maynard_Keynes.
} 
Sections three and four deal with the focus of this inquiry that is the direct and indirect effects that result from the hegemony of the neoliberal ideology and the resulting practical outcome of the globalization/financialization process on social economy. Finally, a very short section will be reserved in order to draw some conclusive remarks.

\section{The hegemony of the neoliberal ideology: a short appraisal}

The historical process of the hegemony of the neoliberal ideology is now well known involving not only the ideological combat - between Keynes and Kalesky and the neoliberal members of the Société du Mont Pélerin just before the WWII - but also the conditions and contexts that allowed the emergency and posterior consolidation of the neoliberal rule (Denord, 2002 \& Mirowsky, 2013).

The main features of the changing context are: an effective union activism throughout the developed world gained impact struggling for a higher share of the national wealth and putting pressure on corporations and on the conservative camp; the inflation brought about among other causes by the Vietnam War, the end of the Bretton Woods gold-US dollar standard and the 1973 oil shock that caused a new type of crisis termed as stagflation which the usual Keynesian instruments did not successfully deal with.

The combination of these several phenomena lead to the erosion of the hegemony of Keynesian ideology and consequently opened up avenues for the neoliberal counter attack. Under the leadership of the members of the Societé du Mont Pélerin and other conservative think tanks in the US and in the UK, financed by some millionaires, the neoliberal agenda became increasingly accepted by influential pundits, media editorialists and other opinion makers. As a result of the consolidation of the neoliberal hegemony, many of its ideas became incorporated into the political agenda of conservative and not so conservative people, such as French socialist technocrats, US liberals who supported global free financial movements, as well as Blair's "Third Way" (Rodrik, 2016).

This ideologically-driven paradigm shift was legitimized by many influential people of the academic mainstream, mainly the so called "fresh water" school based in Chicago and an important number of Nobel laureates such as: Becker, Fama, Friedman, Hayek, Lucas, Prescot and Stigler. The "fresh water" school made full use of its academic power to prevent theoretical dissidence not only by restraining the access to top economic journals, but also by defining what should be investigated ${ }^{3}$. As Romer (2016) put it, dissidence could be considered as “... an extremely serious violation of some honor code for anyone to criticize openly a revered authority

\footnotetext{
${ }^{3}$ The argument for the refusal of Akerlof's seminal article "The Market for Lemons..." on the basis that if the author was correct then Economics would be very different! (Cassidy, 2009), or Rodrik (2016a) stating that many orthodox economists when facing criticisms about globalization do not dare to state publicly their agreement with his cautions about trade because they do not want to give "ammunition for the barbarians".
} 
figure". This hegemony of this anti-keynesian paradigm shift has been powerful enough to ensure the persistence of a number of myths associated with the neoliberal ideal of market functioning (Stiglitz, 2017). Myths such as: the assumption that unemployment does not truly exist, but is voluntary, that it is the result of stubborn workers refusing to accept the going wage; the idea that market power does not need to be addressed, which ignores the role of the asymmetry of information and the importance of dealing with different degrees of market power that this fact implies. And last but not least, that economic agents are rational, markets are efficient and should be self-regulated and the system is stable ${ }^{4}$ !

Only recently those myths started to be debated among the economic mainstream ${ }^{5}$.

The central message of the neoliberal hegemony is that a self-regulated market and careful management of the money supply by independent central banks are the sole recipes for a sustainable state of affairs. Therefore, State power should be severely dimisnished through privatization and by using budget restraint, a move known as "starving the beast". This neoliberal agenda was reinforced and spread worldwide by international organisms such as the IMF, the World Bank and the OECD based on an interpretation of the Williamson's Washington Consensus, which particularly focused on privatizating, liberalizing and deregulating, while ignoring other items that the author supported (Rodrik, 2006) ${ }^{6}$.

\section{The neoliberal ideology and common sense}

Probably, the most important feature of the neoliberal ideology is the struggle to spread an ideal based on the rejection of State intervention, along with a diffuse rejection of the traditional trade union movement. Putting it in another way, it involves the recurrent efforts to reject class theories.

Neoliberal ideology gives legitimacy to refuse what has been called the Welfare State and its redistributive policies, and indirectly accepts that personal taxation is evil, even for the wealthiest, on the grounds that their personal incomes are nothing but the result of personal success stories and, consequently, taxing them is nothing more than an illegitimate confiscation mechanism.

The role of media (Martin \& Yurukoglu, 2017) was (and still is) of paramount relevance in shaping popular common sense to accept neoliberal ideology.

\footnotetext{
${ }^{4}$ See Fama and Lucas' quotes just before the crisis. https://www.brainyquote.com/quotes/quotes/e/eugenefama582058.html and "Mortgages and Monetary Policy", The Wall Street Journal, September 19, 2007 at https://en.wikiquote.org/wiki/Robert Lucas Jr.

${ }^{5}$ Among many others, see: IMF (2013) and Wren-Lewis (2017).

${ }^{6}$ Note the failed attempts made by Stiglitz, at the World Bank, to change the neoliberal rule (Stiglitz, 2002).
} 
It is certain that these neoliberal ideals are not fully accepted and the majority of people still praise most of the Welfare State characteristics, as many polls recurrently show. However, there are always wastes, mismanagements and stupid bureaucracies involved in welfare policies that are motives to be exploited by the media to spread the idea that the problem does not involve particular cases, but is in fact a generic failure.

It seems logical that one of the main reasons explaining the acceptance of the neoliberal ideology comes from the confluence between individualism and what we can consider as generic common sense, which means that it becomes acceptable to follow this common sense when promoting and enforcing policies and, therefore, looking with distrust at anything that is contrary to that view. There are a multitude of examples such as the widespread wrong idea that confuses State finances with households, therefore giving ammunition against State intervention, even when it is most needed, as happened with the pro austerity field during the last crisis.

This acceptance is also linked to the idea of the American Dream - so attractive to migrants and people in general - proclaiming that enough hard work and personal skills will take you to the top of the social ladder. This probably explains the dubious attitudes toward taxation and redistributive policies during this large period of increasing inequality, which represents, in practice, the denial of the American Dream (Manza \& Brooks, 2014). It is dubious because recurrent polls state that American people do not know the true extension of the inequality and if they did, they would not like it. While the situation in Europe is different, also considering that such a thing as the American Dream does not exist, one should not dismiss the power of attraction of an ideology dominating at the hegemon and the influence of the message transmitted by the media: a sign of this is the importance given by the media to Tax Freedom Day.

In short, the international news agencies and the popular media have succeeded in globally spreading these views and, nowadays, we can assume that many of its components have been pervasive in most occidental societies and cultures, which means that they have started to be considered as normal by the common sense.

Furthermore and particularly concerning SE, this generalized common sense influences the public perception of what is in fact social economy, accepting a number of myths that could harm the existence of SE institutions. In particular, the idea that all institutions should share an "enterprise type" of management, either capitalist, public enterprises and/or SE institutions, which reinforces the ignorance about what a SE institution means and induces even specialized economic journalists to identify members of a mutuality as shareholders and the rule one man one vote as representing the capital of the institution (https://shar.es/1Qec1Q)!

Indeed, since the main substratum that shape the common sense is highly formatted by the neoliberal view, it is not strange that business values such as the shorttermism dependence on quarterly results, the overvaluation of the action of the so 
called "business genius" and the consequent outrageous self-awarded rewards, are considered "natural" and therefore can be solely regulated by the market.

Consequently, simple distrust of the State, opportunism or concordance with the neoliberal views, make dodging taxes a pervasive behavior. A large number, if not the majority of people of the so called western civilization are very far from the point underlined by Herbert Simon quoted by Dillow (2016) "that we westerners owe our fortunes not so much to our own efforts but to the good luck of living in societies which enable us to prosper - which have peace, the rule of law and material and intellectual resources."

Another example comes from the neoliberal cathedral: quoting Zingales (2012) "Experimental evidence suggests that the teaching of economics does have an effect on student's behavior; It makes them more selfish and less concerned about the common good. This is not intentional. Most teachers are not aware of what they are doing." Also Kwak (2016) referring to the Foundation for Economic Education and the non-profit Council of Economic Education's efforts to improve economic literacy using simple models implying that "... trade is always good for all parties, taxes and regulations (like rent ceilings) are always bad, and competition is always good for consumers."

After this short overview of the process that is behind the rise and consolidation of the neoliberal ideology and its resilience after the shock of the Great Recession, it is justified to observe some of the main aspects of globalization/financialization and its impacts on public economy and on social economy.

\section{From globalization to financialization: highlighting some impacts}

Financialization is a relatively new concept used to underline perhaps the main characteristic of globalization, here understood as the current phase of capitalist development (Moreira, 2017). As many authors have demonstrated, the global reach of the phenomenon, its intensity and the increased velocity of propagation of the financial flows and its impacts, are different from previous periods of capitalist development.

Liberalization, privatization and deregulation, the three main characteristics of the neoliberal interpretation of the Washington Consensus gave origin to a new period of a global economy based increasingly on foreign trade and investment and to a surge of worldwide capital movements, almost without control. That is, taking advantage of a number of technological innovations - information technologies, cheap transportation, containerization, and others - intermediary activities, such as the big global distribution and retail chains, the information platforms (Google, Yahoo, Facebook, Airbnb, Uber etc.) as well as the more or less speculative financial intermediaries like the hedge funds and the particularly disturbing "vulture funds", global corporations have been able to change the ways of doing business while reinforcing their monopoly power (Kurz, 2017). 
Knowing that the overwhelming daily global finance movements are made within the virtual world, it makes sense to distinguish it from the real economy that deals with real business involving trade of goods and services. Furthermore, one needs to be aware not only of the multiple perverse effects of this financialization, namely the instability provoked by the succession of bubbles and crises (Krugman, 2013), but also of the increasing chances of the collapse of the system, such as the menace provoked by high-frequency trading (Lowenstein, 2012). The virtual economy fueled by financial innovations not only favored the emergence of the Casino economy, but also served to give importance and political influence to financial interests to a point that, nowadays, they are much more able to capture the entities created to regulate them as well as other State institutions, either from the legislative, executive or judicial sphere.

These movements at the core of the globalization/financialization process, provoked a fundamental change in the balance of power between capital and labor (Harvey, 2011), increased economic and social inequality and contributed to the erosion of the income of the majority of working people in the developed world, except for the outrageous remunerations of top managers, while capital gains reached levels never attained since the period prior to the Great Depression of the thirties (Johnson, 2009: 1).

Interestingly, all the above-mentioned changes occurred under the rhetoric of the minimum State, but neoliberalism is performative as Dillow (2012) put it and has been able to use State power to impose politics with worldwide impact and without any democratic accountability that served to increase the power of oligopolistic transnational corporations, namely finance, technological and goods distribution and retail. Standards (Busch, 2017), patent recognition and respective enforcement along with trade agreements (WTO), financial liberalization and privatization, fostered foreign investment, while giving outrageous guarantees to investors to the detriment of democratic nation-state decisions.

Simultaneously, the heterogeneity of fiscal laws, accepted when not supported by the hegemons (the US and the EU) favored the multiplication of fiscal havens (Palan, 2009). Fiscal havens that have become one of the main instruments used for the capture of the State, which became the target and the subject of financial blackmail, through the menace of delocalization and capital flight, counting on the assistance of the main rating agencies, non-accountable and democratically irresponsible institutions that gained the power to impose neoliberal policies by blackmailing democratic governments.

That is to say, many of the economic mainstream look at the economy and particularly at the financial system from a simplistic technocratic point of view, not paying attention to the question of power relations involved in the rise of oligopolies and in capital concentration. This results on a general acceptance of the policies as 
well as judicial decisions that restrain collective bargaining power of labor and therefore are a strong inequality-driving factor (Scocco, 2016).

Moreover, until quite recently, the economic mainstream shows little or no concern for those impacts on ordinary people, therefore ignoring the negative effects that a self-regulated financial system and financial innovations can provoke. When confronted with this reality, they dismiss the issue by stating the losers will eventually be aided by the winners, which does not happen at all ${ }^{7}$. In fact, existing opposition to the neoliberal hegemony still does not reach the decisive political realm.

In brief, a global financial system that not only gave rise to institutions too big-to-fail, but was also very efficient in preparing ways to allow the emergence of institutions too big-to-tax, which substantially contributed to the increase of State debt and to the emergence of the sovereign debt crisis.

It should be noticed that these mechanisms seem strong enough to: assure the capture of the governments by financial interests while ignoring whistleblowers (Kimball, 2013); influence national legislative and judiciary bodies; diminish the capacity of the State to tax the wealthy and the corporations and, at least until the last crisis, promoted the substitution of State regulation for business self regulation. In short, it results in the empowerment of capital in detriment of labor.

Highlighting the perverse effects of finance capitalism is not new so it is of interest to synthetically enumerate some of the main issues that financialization has brought about.

Epstein (2001) referring that central banks' obsession with inflation control has been particularly beneficial to rentier capitalism ${ }^{8}$. Orhangazi (2006) called attention to the crowding out of real investment due to financial investments and profits corroborated by Moreira (2017), who drew attention to the crowding out of private investment within Portuguese agriculture. Thomas Palley (2007) enumerated the principal impacts of financialization: "(1) elevate the significance of the financial sector relative to the real sector; (2) transfer income from the real sector to the financial sector; and (3) increase income inequality and contribute to wage stagnation." Premonitory warnings suggest that there are reasons to believe that financialization may render the economy prone to risk of debt-deflation and prolonged recession. Stockhammer (2010) highlighted:

“(1) changes in household behavior, in particular with regards to household debt, (2) changes in the behavior of non-financial business, such as shareholder value orientation and increased financial activity and (3) changes in the financial sector, in particular the emergence of the (hardly regulated) shadow banking sector, a shift towards household credit (rather than business credit) and a shift to investment banking/fee generating business".

\footnotetext{
${ }^{7}$ See the panel interventions at the IMF (2013) conference "Rethinking Macro Policy II", namely Romer and Stiglitz inputs.

8 "Deflation is hell for workers and business owners, but it's heaven for creditors" Krugman (2011).
} 
Among the many dimensions by which financialization can be approached, the ones related to investment seem particularly relevant to productive activities, to local development and to social economy.

That is the widespread incentives to use all the financial instruments available to the consumer or to provide leverage to capitalist ventures contributed to the mismanagement of bank credit (Bezemer \& Hudson, 2016).

On the other hand, the profits of the financial sector make it very attractive to capital owners and attract the better students to choose careers in the financial sector instead of looking for research or technological development.

Firms have also been induced to change their behavior, particularly when the business management orthodoxy started to put the creation of value for the shareholder as its top preference, if not its only goal.

Management theories and corporate strategic decisions changed the priorities of corporate behavior that legitimate a short-term business vision that requires quick returns from the invested capitals. It is also important to acknowledge the costs of abandonment of an investment in the real economy compared with the substantially inferior risks of financial investments, particularly when, as was happening up to the current crisis, the financial sector was considered safe for investors.

As Economics is a discipline that puts incentives as its core concern, it is ironic that only a few economists showed some concerns about the perverse incentives induced by financialization prior to the Great Recession!

Furthermore, seeing the profits and the potential increase of management compensation provided by financial activity, many corporations formerly involved in production gave new goals to their financial branches to enter into financial activities, which for many, prior to the Great Recession, already provided the larger share of their profits.

In brief, it is now clear that self-regulated markets have been the most desirable gift for businesses in general, but particularly to the ones involved in intermediary actions such as financial business, not to mention those that operate on the brink of legality or commit fraudulent acts (Dyck, Morse \& Zingale, 2013) without concern for the effects that their actions might provoke to individuals, to society and to the environment.

\section{Social Economy in the neoliberal age}

Drawing on the above-mentioned general background one should look at the direct and indirect influence on social economy (SE) of neoliberal ideology and governance.

Broadly, we can take for granted that neoliberal market fundamentalism always prefers SE institutions to direct State intervention. However, this general 
consideration needs to be qualified, since neoliberal pragmatism can show two distinct pathways toward SE: when SE is not only accepted but is warmly welcomed and when SE is, at most, tolerated when not clearly discouraged.

\subsection{Welcomed SE institutions}

In general, neoliberalism welcomes SE institutions when they act in economic territories and activities that are not attractive to profit-driven ventures. In those situations all SE initiatives can be seen as the best ways to restrain State activity, being from the neoliberal point of view, the "perfect substitute" for State intervention.

I am referring to SE philanthropic initiatives, a disguised form of charity that grants to the donors tax rebates and a good media image. Initiatives involving services and aid to the poor, mainly the elderly and or handicapped, as well as those providing help and shelter to refugees, aid to minorities and development of poor countries.

Last but not least, the role of some foundations is welcomed as a means to preserve patrimonies with a privileged use granted to the owners and their descendants, which for many of them, in reality, is nothing more than an institutional legal device to avoid taxation, that is, a neoliberal win-win solution that provides tax breaks to the wealthy without any concern about the perpetuation or aggravation of the inequalities.

But one has to ask the vexatious question: is it really the "perfect" solution? Can SE institutions alone, without State assistance, achieve the proposed goals?

It is clear that, when an activity is not attractive to private businesses, one should think about two possibilities: either they are very risky, either they cannot provide enough results to be economically sustainable.

Therefore, if those initiatives are designed to address issues that are necessary to provide public goods or to satisfy the needs of a community, they need the State and have total legitimacy to ask for it. However, neoliberals demonizing direct State interventions only accept one form of State action, that is, through subsidization of SE initiatives viewed as social civil initiatives (very often religiously based). This is a politically winning position, since political support is obtained not only from the direct beneficiaries, but also from the high number of volunteers involved, not to mention the media goodwill. It should be noted that, seeking this wider political support, neoliberals do not bother to favor more expensive solutions, as we will see below.

By consequence, although these cases can be considered the "perfect" solution from the neoliberal point of view, one must question the problems that such a solution can bring with it.

In general, those SE institutions and activities, which are an expression of the action of civil society, do not raise any objection from a broad range of political positions 
from the left to the right. However, one must be aware that this general consensus can be broken and for good reasons: this refers particularly to those cases where SE activity is understood to be a means to impede State solutions provided for anyone, while SE institutions would provide only parceled solutions.

This is particularly the case of SE institutions having activities that seek to produce solutions that could hamper a universal health system turning it into a weaker dual system, a rich one for the ones who can pay and a poorer State system aimed primarily for the dispossessed.

Concluding, from a neoliberal point of view and for these types of cases, SE institutions and actions either serve a direct political purpose of giving disguised tax breaks to the wealthy, either they serve a more indirect but welcome effect of avoiding "unnecessary" State lead solutions or, what is even more damaging, can contribute to eroding State action only on the ground that, from the neoliberal or libertarian perspective, it is ideologically illegitimate.

\subsection{Tolerated SE}

There are many cases which neoliberalism only tolerates, when they do not discourage SE institutions. However, cooperatives and mutualities, that sucessfully compete in the market and therefore could hamper the development of capitalist ventures, are discouraged.

In short, giving that the ultimate goal of neoliberalism seeks to expand for-profit markets to every realm of social and individual life, it only welcomes SE initiatives that do not compete in pro-profit markets, while trying to restrain the scale and the scope of the non-profit and non-capitalist ventures in those markets.

In fact, it is an extremely smart strategy that involves several lines of action: within the national realm, it acts on the ideological and managerial realm to discredit the SE able to compete in the market, on the grounds that it is not efficient and/or is not able to obtain the necessary capital to develop its activities. This move is further reinforced by some ignorant business media ${ }^{9}$. It also acts on the regulation and legislative realm, by designing specific laws that could pervert the founding values of SE and pushing for their enforcement, even though these are protected by the Portuguese Constitution. Finally, it takes advantage of the ignorance and/or malfeasance of some bureaucrats, placed in relevant nodes of the decision making process.

But also, at the EU level, the acceptance of the label "social", such as the "social enterprise" that in fact could be a disguise for pro-profit ventures.

\footnotetext{
${ }^{9}$ That is, applying the rhetoric that it is necessary to explore all means of financing, attracted SE management boards are enticed to break with SE values and principles.
} 
This helps to explain why, in several fora, from the neoliberal think tanks and media, to Parliaments and to Governments and regulation boards ${ }^{10}$, there are plenty of examples of attempts to hamper cooperative solutions, as well as mischaracterizing mutualism and cooperative principles. A particularly relevant case concerns the 2011 decision of the European Commission attempting to restrain the scope of SE in the fight against poverty and social exclusion (Monzón, 2016).

\section{Financialization and Social Economy}

Financialization and its impacts on SE involves different forms of looking at reality, namely identifying the specific impacts of financialization on the different types of SE institutions, understanding its role involved on access to financial resources that any institution needs to develop any kind of activity and, last but not least, clarifying the role of the State on the development of the neoliberal agenda towards SE.

As it has been stated above, neoliberal ideology looks at SE institutions in accordance with their role and type of activity, therefore it seems logical that neoliberal-driven policies will impact SE differently.

In general, SE institutions that do not compete with capitalist business are to be favored, but not on a universal basis. They will certainly count on State support if their activity could substitute direct State intervention but, when that is not the case, State support will only be granted after choices involving pragmatic political decisions. In fact, choice means favoring constituencies and groups of interest with political power and ignoring others; this explains why many SE institutions, located in less favored zones without political power to demand State support, are mostly unsuccessful in receiving it, even when not competing with capitalist business.

On the contrary, SE competing with capitalist ventures can count on an array of political measures, directly or indirectly ideologically-driven, that could hamper their action. It is from this perspective that one can understand the number of direct measures and indirect ways used by neoliberal power, with the connivance of the media, to mischaracterize social economy perverting basic democratic values and founding principles.

Particular attention must be given to the attempts to circumvent the rule of one man one vote by granting voting rights to capital, or by allowing private appropriation of profits or plus values obtained by collective action, particularly in the absence of clear rules to prevent it in the case of dissolution.

All these issues involve direct political measures, such as laws that point to the demutualization and/or the mischaracterization of cooperatives as well as the political innovations that involve the support granted to a "perverse" idea of social economy

\footnotetext{
${ }^{10}$ Such as the decision of the Portuguese competition regulation board preventing a dairy cooperative merger, while accepting an identical result but under a private form of business - LACTOGAL S.A - totally owned by the cooperatives.
} 
such as the "social enterprises" that not only involve private capitalists but ensure that they will be able to obtain profits and/or plus values.

\subsection{Financing SE and the neoliberal State intervention}

Financing SE involves two main sources of financing resources: through direct or indirect State intervention and/or by bank and/or financial markets.

As it has been mentioned above, from a strictly ideological point of view we can have: a) neoliberal governments welcoming the SE; b) neoliberal governments dealing with a SE competing with capitalist businesses.

Starting with a) we can find different situations. When the purpose is obtaining the means to ensure the safeguard of patrimony, cultural and/or charity, the neoliberal rule tends to be benevolent and, accordingly, it does not refuse giving support in a variety of ways. These range from tax exemptions or rebates, to subsidies, and making partnerships where the State can give subsidies or when not providing direct financial support serves to assure risk protection. Foundations usually rely on private resources and therefore State intervention means essentially receiving indirect support policies, but other SE institutions such as the Portuguese IPSS (Instituições Particulares de Solidariedade Social - Private Institutions for Social Solidarity) could not subsist solely on donations and only subsist through State subsidies. Finally, other associative SE institutions, such as many NGOs, can imply different sources of financing, ranging from donations and aid directly granted by the State or partnerships between the State and the SE institution with the State being the financing partner.

In short, for these types of SE institutions the amount of financing obtained directly or indirectly from the State depends on the resources available, as well as on the political purposes involved, either domestic or geopolitical.

In fact, direct and indirect financial support needs to comply with budgetary limits, particularly in the Eurozone context, due to the boundaries fixed by budgetary treaties.

However, those limits do not only depend on State resources, but also depend on an ideologically-driven political pragmatism, regardless of its democratic legitimacy. The following Portuguese example will help to enlighten this issue referring to social policy developed by the neoliberal government during the Troika period (2011-2015), when social policy underwent a great change. It was a period when unemployment skyrocketed resulting in a strongly increasing demand for handouts, but in accordance with the neoliberal ideology the subsidies for the unemployed were strongly reduced, from $78,6 \%$ of the number of unemployed receiving subsidies in 2009 to only 51,9\% in 2015; also the value of pensions was reduced and their access was severely restrained; access to the National health system became more difficult by increasing the so called moderating taxes and, finally, the access to the minimum 
income guarantee (MIG) was strongly restricted, from more than 526 thousand beneficiaries in 2010 to less than 296 thousand in $2015^{11}$. All these reductions were announced as a need to comply with the lack of State resources due to the sovereign debt crisis that brought the Troika supervision. The political choice was crystal clear, at the same time that the MIG, pensions and unemployment subsidies diminished and their access was severely restricted and all this at a time of skyrocket unemployment, State subsidies to charity substantially increased, namely to provide food for the poor. Ironically, it is interesting to note the subsidies granted to IPSS for social canteens was fixed on a basis of 600 Euros/month for each person served, which is substantially higher than the average amount conceded as MIG. This is politically understandable when we know that this option involved the proliferation of partnerships between the State and the IPSS, most of them connected to the Catholic Church, which is dominant in Portugal.

With regard to SE competing in the market, it is obvious that direct State support will only be granted in particularly politically sensitive cases and indirect support, such as tax exemptions, will only be granted if there are constitutional rights or there is very strong public support that would make any cut impossible or very difficult to assume politically. For instance, the Portuguese constitutional right, determining positive discrimination that should be granted to cooperatives, has different interpretations, ranging from examples of goodwill to a number of bureaucratic practices that, by ignorance or malfeasance, not only ignore this constitutional right but also hamper the economic performance of cooperatives. It is well known that it is particularly difficult to conciliate competition rules with this constitutional right particularly when bureaucrats and politicians ignore what is at stake.

Finally, when looking at the process to obtain resources through State intervention, what have been stated above does not only refer to neoliberal governments since, as has happened in recent UE policies, even governments opposed to the neoliberal rule are forced to comply with neoliberal rules, as Greece and Portugal know by direct experience.

\subsection{Access to the bank or financial markets}

The differences between the above mentioned SE institutions are also visible. First of all, among SE institutions that do not compete in the market, the situation is quite different if the financial resources needed to develop their activity are mainly obtained through donors, as well as many charities and NGOs, which implies that bank credit will only be used to comply with treasury needs, but does not imply investment and/or financing potentially risky activities.

Foundations could easily find bank credit or financial resources, which is only limited by the value of their patrimony that serves as collateral.

\footnotetext{
${ }^{11}$ Following UK and Australia's guidelines so well described by the Ken Loach film "I Daniel Blake". The figures mentioned were obtained at the PORDATA data base accessible at http://www.pordata.pt.
} 
Much more complicated is the situation of SE institutions that compete on the market, both the product and the service market. The following applies particularly to cooperatives.

The characteristics and rules of cooperatives pose some restrictions when accessing banking and financial markets.

When we consider banking access for investment, the need to have enough collateral to obtain finance from banking sources should be noted. When the existing collateral is not enough for the amounts required for investment, SE institutions face a dilemma: not invest and therefore lose opportunities to develop and to compete in the market, or try to invest using short-term credit to be rolled out as a substitute for a long-term investment loan. This is a managerial error that unfortunately many poorly managed cooperatives made and led many cooperatives to unsustainable pathways and bankruptcy.

This panorama is a powerful argument to seek alternative forms of financing for SE activities. However, seeking alternatives to bank credit can signify substantial differences: a) alternatives that comply with SE founding values and b) alternatives that more or less pervert those values.

The first solution requires SE to have financial nerve and use it, such as the example of Mondragon that since its inception considered that a financial branch was vital. For other cooperatives that do not have these group financing alternatives, the possibilities to access financing are more restrained, making them hostages of the commercial banks, which means that financing depends mostly on the level of collateral they possess. Furthermore, if in many countries SE banking institutions do exist and have substantial nerve, such as in Canada with the Group Desjardins, in Portugal, these were forbidden during the 48 years period of dictatorship that ended in 1974. And, after that, the political power and the banking regulators in general were not particularly happy with the emergence of a SE banking sector as the difficulties involving the formation of the agricultural Caixas de Crédito Agrícola Mutuo and its central body illustrate.

However, it could be possible in many cases to circumvent financing difficulties, but this would require good levels of trust and goodwill between the members of the cooperative and the cooperative leadership being able to share their views.

Directing a study to rescue some dairy cooperatives in difficulties, we found that the majority of members would accept to make direct loans to the cooperative by agreeing to receive a smaller amount of money for each liter of milk delivered. The difference from the ordinary price would constitute a personal account of loans to the cooperative that would get the exact amount of interest that the member could get on a banking account. By using this process the cooperative could satisfy many of their financial needs by paying substantially reduced interest and without need of 
collateral. Unfortunately, cooperative leadership did not show any particular enthusiasm and the trial did not take place.

Another possibility of obtaining financial resources, without harming cooperative principles, implies making feasible the use of socially responsible bonds aimed specifically at financing SE institutions. Nevertheless, to achieve this, a number of collective actions are needed not only involving SE institutions needing financing, but also involving SE institutions involved in banking and insurance areas to give support to the issue of these bonds. Finally, assurance is necessary from the State institutions and bank and insurances regulators that, even if they do not facilitate those instruments, at least they will avoid hampering them.

Any request from the SE institutions needing finance involves the preparation of good projects. That is, projects that are not only necessary for the existence of the institution and for the communities involved, but also that could be viewed as necessary and deserving of funds from the point of view of an investor.

From the point of view of the State and from the point of view of the regulators such bonds should merit positive discrimination, not only because they will involve investments in the real economy with many of them aimed at producing common goods, therefore contributing to the well being of society, but also because they could contribute to a less volatile financial market.

However, a note of caution needs to be made. As will be referred below, we are considering only social investment bonds that could be compatible with SE values and cooperative principles, since solutions that do not care about the SE values and principles are, in fact, what is most favored and actively proposed by the neoliberal rule!

These options require that SE representatives will accept capitalists' rights to vote according to the amounts of capital invested. The worst case is when, in the absence of strong opposition, surplus or plus values obtained by patrimony alienation could be privately appropriated, thus contradicting the founding cooperative principles.

A situation of particular concern results from presenting these options as the sole means of escaping financial difficulties, which signify that, when the alternative is financial collapse, the obvious escape would be to comply with the creditors' requests.

Nevertheless, what is probably more problematic is the insidious luring process that employs many different ways to lead cooperative members to forget cooperative values or when existing cooperatives do not comply with their duties to teach cooperative values and therefore pave the way to a non-critical acceptance of common sense. For instance: the ideological bombardment labeling collective action as a disaster, ignoring Elinor Ostrom's demonstration that the "tragedy of the commons" is not a fatal pathway but, on the contrary, that collective action is not 
only a winning bet, but a necessity; or ignoring successful cases but highlighting examples of poor cooperative leadership and management, therefore giving ground to the claim for an "enterprise type" of management that in fact does not take into account cooperative values and principles; and the direct and indirect pressure made by financial or competing interests to overcome cooperative values in order to ensure that good and competitive cooperatives can be involved in schemes such as mergers and/or partnerships with capitalist ventures, namely by granting them access to cooperative's facilities. Not to mention the lack of principle in accepting behavior by dishonest people who wish to appropriate private profits by privatizing what was previously a collective venture.

Another recent and fast growing development refers to the "new logics of social investment" (Ferreira, 2016) involving the issue of "social investment bonds" or "social impact bonds" aimed at attracting capitalists to invest in social projects or policies.

This new logic, adopted by investors connected with large financial groups ${ }^{12}$ as well as by the European Commission, is quite different from the logic of the socially responsible bonds referred to above. It should be understood as another piece of the neoliberal project of fostering "social entrepreneurship" and "social enterprises" and, consequently, is aimed at expanding the pro-profit market to areas and policies that, until now, were dependent on State initiatives or true social economy institutions.

\section{Conclusive remarks}

Highlighting the importance of the neoliberal ideology in formatting the vision of the hegemonic political spectrum that rules, almost unchallenged, in Western democracies, constitutes the relevant background used in this text to better understand the impacts of financialization on social economy.

In fact, it was the neoliberal ideology that, with the support of the mainstream media, succeeded in establishing as conventional wisdom this particularly pernicious economic vision of market fundamentalism. The hegemony of the neoliberal ideology owed a lot to the benevolence of the economic mainstream that, by voluntarily ignoring issues, such as the disproportionate power of capital not only in its relations with labor but also on the fundamental question of the capture of the State, contributed to legitimate neoliberal policies.

One particularly important aspect of this process of dominance of market fundamentalism, achieved by liberalization and de-regulation, was the idea that restricting the negotiating power and/or avoiding State controls was not only perfectly natural, but also desirable. Ideas accepted by politicians and the judicial

\footnotetext{
${ }^{12}$ GIIN (Global Impact Investing Network), created by Crédit Suisse, Deutsche Bank, Goldman Sachs and UBS (Alix \& Baudet, 2015).
} 
corps that contributed to the rising inequality typical of financialization and to the emergence of the Casino economy.

Looking at the impacts of the financialization process over social economy, one must stress the growing importance given by the neoliberal ideologues and politics to the use of SE institutions as a substitute to the State, in a way that would not provoke the same popular opposition as the single cuts of State functions, therefore serving the ultimate neoliberal goal of spreading market relations to every area of human activity.

The interest given by the ruling class to support the idea of "social entrepreneurship" and "social enterprises" by using all the means of the European Commission, as well as the practical examples used in Portugal by the government when the Troika was supervising the use of the budget are proof enough. Moreover, when the conventional wisdom of the neoliberal vision consolidates, it becomes a powerful device to mischaracterize SE institutions in order to accept pro-profit capital as a legitimate means to fulfill their purposes.

In consideration of these issues, a framework has been established to evaluate what the issues are and which one should be considered by each particular type of SE institution, when dealing with access to finance, particularly underlining the pernicious effects that could result from the lack of attention to the founding values of social economy.

\section{References}

ALIX, N., BAUDET, A., La mesure de l'impact social : facteur de transformation du secteur social en Europe, Working paper CIRIEC N²014/15, http://www.ciriec.ulg.ac.be/wp-content/uploads/2015/08/WP14-15.pdf, 2014.

BEZEMER, D., HUDSON, M., "Finance Is Not the Economy: Reviving the Conceptual Distinction", Journal of Economic Issues, Vol. L no 3, 2016.

BUSCH, L., "Standards and Their Problems: From Technical Specifications to World-Making", in Mara MIELE, Vaughan HIGGINS, Hilde BJØRKHAUG, Monica TRUNINGER (ed.), Transforming the Rural (Research in Rural Sociology and Development, Volume 24), Emerald Publishing Limited, 2017, pp. 97-114.

CASSIDY, J., How Markets Fail. The Logic of Economic Calamities, New York, Farrar, Strauss and Giroux, 2009.

DeLONG, B., "The Need for a Reformation of Authority and Hierarchy Among Economists in the Public Sphere", in http://www.bradford-delong.com/2017/03/the-need-for-areformation-of-authority-and-hierarchy-among-economists-in-the-public-sphere.html, 2017. 
DENORD, F., "Le prophète, le pèlerin et le missionnaire", in Actes de la recherche en sciences sociales 5/2002 (no 145), p. 9-20, http://www.cairn.info/revue-actes-de-la-recherche-ensciences-sociales-2002-5-page-9.htm.

DILLOW, C., "Irvin Berlin on Taxes",

http://stumblingandmumbling.typepad.com/stumbling and mumbling/2016/01/irvingberlin-on-taxes.html, 2016.

DILLOW, C., "Performativity in policy",

http://stumblingandmumbling.typepad.com/stumbling and mumbling/2012/11/performat ivity-in-policy.html, 2012.

DORMAN, P., Financialization and the Incredible Shrinking Time Horizon, http://econospeak.blogspot.pt/2013/05/financialization-and-incredible.html, 2013.

DYCK, A., MORSE, A., L. ZINGALES, How Pervasive is Corporate Fraud?, in https://papers.ssrn.com/sol3/papers.cfm?abstract id=2222608, 2013.

EPSTEIN, G., "Financialization, Rentier Interests, and Central Bank Policy", Paper prepared for PERI Conference on "Financialization of the World Economy", University of Massachusetts, Amherst, December 2001.

FERREIRA, S., "As novas lógicas do investimento social", http://www.esquerda.net/artigo/novas-logicas-do-investimento-social/45420, 2016.

HARVEY, D., O Enigma do Capital e as Crises do Capitalismo, Lisboa, Editorial Bizâncio, 2011.

IMF "Rethinking Macro Policy II",

http://www.imf.org/external/np/seminars/eng/2013/macro2/index.htm, 2013.

JOHNSON, S., "The Quiet Coup", in The Atlantic,

http://www.theatlantic.com/magazine/archive/2009/05/the-quiet-coup/7364/, May 2009, $12 \mathrm{p}$.

KIMBALL, M. "When Honest House Appraisers Tried to Save the World", http://blog.supplysideliberal.com/post/56117013842/when-honest-house-appraiserstried-to-save-the-world, 2013.

KRUGMAN, P., "This Age of Bubbles",

http://www.nytimes.com/2013/08/23/opinion/krugman-this-age-of-bubbles.html, 2013.

KRUGMAN, P. "The Rentier Regime”, http://krugman.blogs.nytimes.com/2011/06/06/therentier-regime/, 2011.

KURZ, M., "The New Monopolists",

https://www.project-syndicate.org/commentary/monopoly-power-wealth-incomeinequality-by-mordecai-kurz-1-2017-09, 2017.

LOWENSTEIN, R., "A Speed Limit for the Stock Market", in The New York Times, http://www.nytimes.com/2012/10/02/opinion/putting-the-brakes-on-high-frequencytrading.html, 2012. 
MANZA, J., BROOKS, C., Prisoners of the American Dream? American's Attitudes Towards Taxes and Inequality in a New Gilded Age. Accessed at 7-01-2016, in http://sociology.as.nyu.edu/docs/IO/3858/PrisonersoftheAmericanDream.pdf, 2014.

MARTIN, G., YURUKOglU, A., "Bias in Cable News: Persuasion and Polarization", in American Economic Review, vol. 107, no. 9, September (pp. 2565-99), 2017.

MIROWSKI, P., Never Let a Serious Crisis Go to Waste: How Neoliberalism Survived the Financial Meltdown, London, NY, Verso, 2013.

MONZÓN, J. L., La Economía Social en la Literatura Económica y en los Hechos: 30 Años de Historia del Ciriec-España. Conferencia pronunciada el 19 de octubre de 2016 en el Paraninfo de la Universitat de València, con motivo del XXX Aniversario de la creación del CIRIEC-España, 2016.

MOREIRA, M., "Impacts of Financialization on Agricultural and Rural Investment: Lessons from the Portuguese Case", in Mara Miele, Vaughan Higgins, Hilde Bjørkhaug, Monica Truninger (ed.), Transforming the Rural (Research in Rural Sociology and Development, Volume 24), Emerald Publishing Limited, 2017, pp. 25-44.

"Impacts of Financialization on Agricultural and Rural Investment: Lessons from the Portuguese Case", in Transforming the Rural. Published online: 03 Jul 2017; 2544. Permanent link to this document:

https://doi.org/10.1108/S1057-192220170000024002, 2017.

ORHANGAZI, Ő., Financialization and Capital Accumulation in the Non-Financial Corporate Sector. A Theoretical and Empirical Investigation on the U.S. Economy: 1973-2003, Working paper number 149, PERI (Political Economy Research Institute) UMASS, 2006.

PALAN, R., "The history of tax havens", in History \& Policy, http://www.historyandpolicy.org/papers/policy-paper-92.html\#S5, 2009.

PALLEY, T., Financialization: What it is and Why it Matters, Working paper number 153, PERI (Political Economy Research Institute) UMASS, 2007.

RODRIK, D., "The Abdication of the Left" in Project Syndicate, July 11, https://www.projectsyndicate.org/commentary/anti-globalization-backlash-from-right-by-dani-rodrik-2016$\underline{07}$.

RODRIK D., "Straight Talk on Trade" in Project Syndicate, Nov. 15, https://www.projectsyndicate.org/commentary/trump-win-economists-responsible-by-dani-rodrik-2016-11, 2016a.

RODRIK, D. "Goodbye Washington Consensus, Hello Washington Confusion?", https://drodrik.scholar.harvard.edu/files/dani-rodrik/files/goodbye-washington.pdf.

ROMER, P., "The Trouble With Macroeconomics", in https://paulromer.net/wp-content/uploads/2016/09/WP-Trouble.pdf, 2016. 
STIGLITZ, J., "The Welfare State in the Twenty First Century", in https://www8.gsb.columbia.edu/faculty/jstiglitz/sites/jstiglitz/files/The\%20Welfare\%20St ate\%20in\%20the\%20Twenty\%20First\%20Century.pdf, 2017.

STIGLITZ, J., Globalisation and its Discontents, W.W. Norton \& Company, 2002.

Scocco, S., "Greater Inequality Not Due To New Technology And Free Trade", in Social Europe, https://www.socialeurope.eu/2016/12/greater-inequality-not-due-new-technology-freetrade/, 2016.

STOCKHAMMER, E., Financialization and the Global Economy, Working paper number 240, PERI (Political Economy Research Institute) UMASS, 2010.

WREN-LEWIS, S., "On criticising the existence of mainstream economics", in https://mainlymacro.blogspot.pt/2017/03/on-criticising-existence-of-mainstream.html, 2017.

ZINGALES, L., "Do Business Schools Incubate Criminals?", in Bloomberg, http://www.bloomberg.com/news/2012-07-16/do-business-schools-incubate-criminals.html, 2012. 


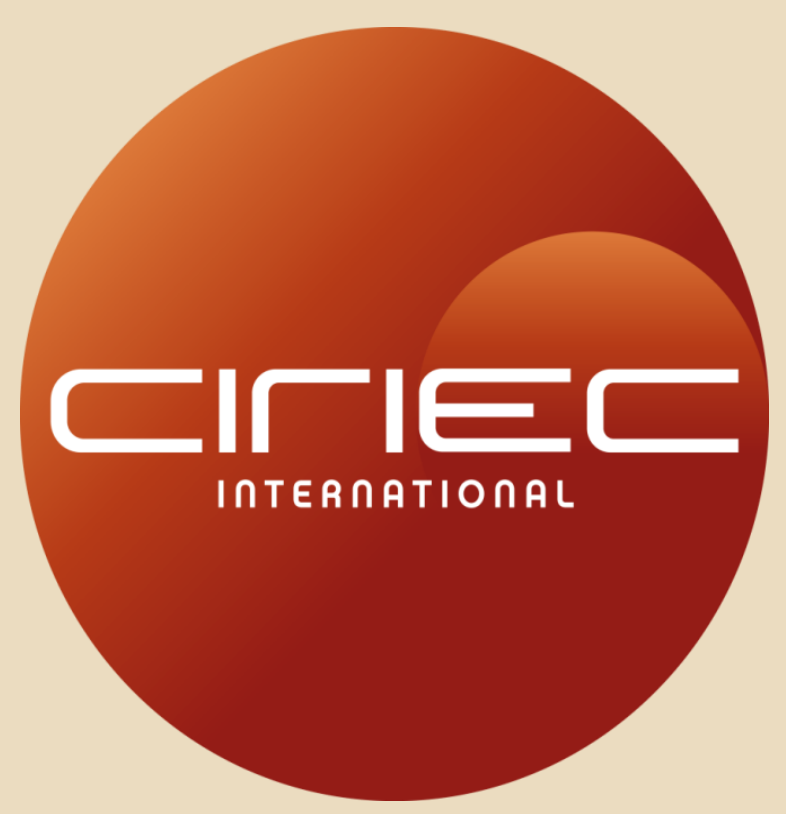

The CIRIEC STUDIES SERIES proposes research results from working groups and commissions of the CIRIEC scientific network in both social and cooperative economy and public economy.

To facilitate accessibility to those research works, this electronic series is proposed in open access, on CIRIEC's website, but also as new series in RePEC.

Each study is available and downloadable as a whole document but also chapter by chapter.

x ciriec@uliege.be

\#ww.ciriec.uliege.be

(https://ideas.repec.org/s/crc/chapte.html 